\title{
Application of nano-curcumin as a natural antimicrobial agent against Gram-positive pathogens
}

\author{
Ruchi Sankhwar \\ Department of Microbiology, Babasaheb Bhimrao Ambedkar University (A Central University), \\ Vidya Vihar, Lucknow-226025 (Uttar Pradesh), India \\ Shilpi Yadav \\ Department of Physiology and Biophysics, University of Arkansas for Medical Sciences, Little \\ Rock, AR -72205, USA

\section{Abhishek Kumar} \\ Department of Microbiology, Babasaheb Bhimrao Ambedkar University (A Central University), \\ Vidya, Lucknow-226025(Uttar Pradesh), India \\ Ravi Kr. Gupta* \\ Department of Microbiology, Babasaheb Bhimrao Ambedkar University, (A Central University), \\ Vidya Vihar, Lucknow-226025(Uttar Pradesh), India \\ ${ }^{*}$ Corresponding author. Email: ravikumarcdri@gmail.com
}

\section{How to Cite}

Sankhwar, R. et al. (2021). Application of nano-curcumin as a natural antimicrobial agent against Gram-positive pathogens. Journal of Applied and Natural Science, 13(1): 110 - 126. https://doi.org/10.31018/jans.v13i1.2482

\section{Abstract}

Gram-positive bacteria cause various diseases from the superficial skin to deep tissue infections. The capability of causing numerous diseases is due to the production of virulence factors which are tightly regulated by the virulence genes. Various Grampositive pathogenic bacteria e.g. Staphylococcus, Mycobacterium, and Listeria are capable of causing lethal infections in humans and animals. Conventional antibiotics, targeted antibiotics, and combinatorial drugs are used as therapeutic agents against Gram-positive pathogens. Due to intricate virulence pathway bacteria readily adopt resistance to available drugs. Therefore, there is need to develop some alternative approaches to combat these infections. Various natural extracts are effective against pathogenic bacteria with or without the available drugs. Curcumin is a natural extract of Curcuma longas rhizome, known as turmeric. Curcumin shows various biological activities such as antimicrobial, antioxidant and anti-inflammatory. It also shows strong antibacterial activity against Gram-positive and few Gram-negative bacteria. Besides all these beneficial applications, major drawbacks of curcumin are poor aqueous solubility and less bioavailability. However, drug delivery approaches including nanoformulation are developed to increase its stability in vitro and in vivo settings. The present review article focused on the translation of potential applications of curcumin in various diseases specifically caused by Gram-positive pathogens. Various methods used for the formulations of curcumin nanoparticles, combinatorial strategies with curcumin nanoparticles and their application in the prevention of infections have been discussed. The present article also discusses the future aspects of curcumin-nanoparticles and its use as an alternative therapeutic approach against pathogens.
\end{abstract}

Keywords: Alternative therapeutics, Antimicrobial agent, Nanocurcumin, Nanoparticles, Natural antimicrobial agent

\section{INTRODUCTION}

The most important Gram-positive human pathogens, such as Staphylococcus aureus, Streptococcus pneumoniae and Enterococci remain as public health menace (Woodford and Livermore, 2009). The major health -care concern is due to the emergence of resistant strains such as methicillin-resistant Staphylococcus aureus (Cornaglia, 2009) and vancomycin-resistant enterococci (VRE) strains (Eades et al., 2017). In developing countries, factors such as poor drug quality, improper drug dosage, the high rate of self-medication (Ayukekbong et al.,2017), unhygienic conditions, contaminated food, and water supply, poor domestic and animal contact attributed to the development of drugresistant strains (O'Neill 2015, Grace, 2015). According to a research, four main factors are responsible for microbial resistance such as (i) noncompliance (ii) incor- 
rect use of broad-spectrum agents (iii) incorrect dosing and (iv) excess antibiotic usage (Niederman, 2005). The genetic material alteration also leads to the formation of resistant strains by mutation, and it can be an innate, intrinsic, or acquired type (Mihaescu et al., 2007, Decoster et al., 2008). Several Gram-positive pathogens are responsible for various diseases such as skin and soft tissue infections, wound infections, urinary infections, gastrointestinal infections, osteomyelitis, endocarditis, pneumonia, thrombophlebitis, inflammation of breast tissue (mastitis), inflammation of the brain and spinal cord surrounded membrane (meningitis), toxic shock syndrome and septicemia (Nair et al., 2014). An antimicrobial substance that kills or inhibits bacterial growth is called antibiotics (Himaniand Joshi, 2019). Various traditional herbs can inhibit the growth of Gram-positive and Gram-negative bacteria and now these medicinal herbs are used for the treatment of microbial infections (Evans et al., 2002). These herbs include Azadirachtaindica (neem), Curcuma longa (turmeric), Acacia nilotica L. (Babul), Withania somnifera (Ashwagandha) (Dhamaet al., 2014). In this review article, we have focused on the therapeutic properties and applications of curcumin, which is an active component of turmeric.

Curcumin is a polyphenolic flavonoid compound obtained by rhizome of turmeric (Curcuma longa L.) (Mun et al., 2014). Diferuloylmethane or curcumin is a major phytochemical component of turmeric (Zingiberaceae family), which is responsible for giving the yellow colour to the herb. Curcumin extracted from turmeric by various methods of solvent extraction e.g., Soxhlet, ultrasonic, microwave, and supercritical carbon dioxide, followed by purification via column chromatography (Li et al.,2014, Priyadarsini, 2014). For many years, curcumin has been used as a pharmaceutical agent because of its antioxidant, anti-inflammatory, anti-carcinogenic, and antimicrobial properties (Epstein et al., 2010; Naksuriya et al., 2014). It has also wound healing and anti-ageing activities (Akbik et al., 2014; Lima et al., 2011). Curcumin also shows beneficial effects to control blood glucose levels and enhanced mucosal gastric secretion in rabbits (Arun and Nalini, 2002). In 1815, curcumin molecules were isolated the first time and in 1873, Roughley and Whiting had given its chemical structure (Rai et al., 2015), in 1873. In 2014, Priyadarsini reported the chemical formula of curcumin as $\mathrm{C}_{21} \mathrm{H}_{20} \mathrm{O}_{6}$ with a molecular weight of $368.38 \mathrm{gm} /$ mole. Turmeric contains approximately $77 \%$ diferuloylmethane (curcumin I), 17\% Demethoxycurcumin (curcumin II), and 6\% bisdemethoxycurcumin (curcumin III) components (Fig. 1) (Aggarwal et al., 2007). Curcumin is hydrophobic in nature contains two polyphenolic rings, which consist of o-methoxy phenolic groups, and curcumin shows tautomerization in a $\mathrm{pH}$-dependent condition (Beevers and Huang, 2011).

\section{FUNCTIONAL ASPECTS AND APPLICATIONS OF CURCUMIN}

\section{Antimicrobial activity}

Naturally occurring substances especially from plants have great potential for controlling food spoilage and infections caused by pathogens. Curcuma is a natural plant product obtained from Curcuma longa widely used in medical application (Salehi et al., 2019). Upendra and his co-workers found that turmeric at a concentration of 0.8 and $1.0 \mathrm{~g} / \mathrm{L}$ showed significant antifungal activity in plant tissue culture (Upendra et al., 2011). Methanol extracted curcumin obtained by the turmeric used against Cryptococcus neoformans and Candida albicans, showed antifungal activity with MIC $128 \mu \mathrm{g} / \mathrm{mL}$ and $256 \mu \mathrm{g} / \mathrm{mL}$. Ungphaiboon et al., demonstrated antifungal activity of hexane extracted curcumin against Rhizobium solani, Erysiphe graminis, and Phytophthora infestans (Ungphaiboon et al., 2005). Curcumin blocks membrane-associated ATPase activity and reduces the secretion of proteinase (Martins et al., 2009). Recently, $\mathrm{Hu}$ et al., reported that curcumin act on endoplasmic reticulum and minimize the effect of in Cryptococcus neoformans infection (encapsulated yeast) (Hu et al., 2017). Sometime Antiviral therapeutics are still in the nest and there is a lack of effective therapeutic therapies, high cost of antiviral therapies and to overcome the chemical side effects, it compels to investigate the properties of naturally occurring compounds such as a component of green tea (Steinmann et al., 2013), cinnamon (Connell et al., 2016), and various types of herbs against viral infections. Curcumin is a pleiotropic molecule with great potency to show antiviral activity against different kind of viruses e.g., hepatitis viruses, influenza viruses, chikungunya virus (CHIKV) or arboviruses, human immunodeficiency virus (HIV), human papillomavirus (HPV), herpes simplex virus 2 (HSV-2) and also effective against sexually transmitted diseases (Praditya et al., 2019). Gopal and his coworkers compared the bactericidal activity of three types of curcumin particles e.g., macro, micro, and nano against Escherichia coli, Salmonella enteritidis12021, Streptococcus mutans11823, and Staphylococcus aureus. The results showed that the bactericidal activity of curcumin nanoparticles was enhanced compared to macro and micro curcumin particles (Gopal et. al., 2016). In a study found that curcumin decorated micelles particles increase the antibacterial activity of miltefosine and alkyl phosphocholines erufosine toward S. aureus pathogenic strain (Zaharieva et al., 2019). It has been found that curcumin (MIC 125 to $250 \mu \mathrm{g} / \mathrm{mL}$ ) was effective against 10 strains of $S$. aureus (e.g., two ATCC MRSA, and MRSA standard strains, four MRSA from culture collection and four MRSA clinical isolates) (Mun et al., 2013). Curcumin with MIC $256 \mu \mathrm{g} / \mathrm{mL}$ also effective against MSSA (methicillin-susceptible Staphy- 
<smiles>[2H]C([2H])([2H])Oc1ccc(/C=C/C(=O)[CH]C(=O)C=Cc2ccc(O)c(O[CH])c2)cc1O</smiles>

(a)<smiles>[2H]C([2H])Oc1ccc(/C=C/C(=C/O)/C=C/C(=O)/C=C/c2ccc(OC)cc2)cc1O</smiles>

(b)<smiles>COc1ccc(/C=C/C(=O)/C=C/c2ccc(O)cc2)cc1</smiles>

(c)

Fig. 1. (a) Structure of Diferuloylmethane (Curcumin I) (b) Structure of Demethoxycurcumin (Curcumin II) (c) Structure of Bisdemethoxycurcumin (Curcumin III) (Raiet al., 2015).

lococcus aureus) (Wang et al., 2016). When curcumin is used in combination with antibiotics such as cefaclor, penicillin, gentamicin, erythromycin, and amikacin, it shows synergistic antibacterial activity (Teow et al., 2016). To understand the curcumin antibacterial activity some researchers demonstrated that curcumin has the potential to interfere with FtsZ (FtsZ homolog in eukaryotes is cytoskeletal tubulin protein) in vitro and stops the FtsZ ring (Protofilament) assembly in Bacillus subtilis, and observed that curcumin inhibits the bacterial cell proliferation by stopping the assembly of FtsZ mechanism (Rai et al., 2008). Therefore, FtsZ is the novel component of bacteria, which can be a drug target for the development of antimicrobial agents against S. aureusatsui et al., 2012; Singh and Panda, 2010). Mun et al.,had shown that in the periplasm of Gramnegative and cell surface of Gram-positive bacteria ATP-binding cassette (ABC) transporters are located. ATP-dependent transporting activity of $A B C$ transporters was inhibited by the curcumin in combination with ATPase inhibitors such as $\mathrm{N}$, Ndicyclohexylcarbodiimide (DCCD), $\mathrm{NaN}_{3}$ by inhibiting the $\mathrm{H}^{+}$translocation activity and stops the growth of $S$. aureus MRSA (Mun et al., 2014) and also noted that penicillin-binding protein (PBP) or PBP2 encoded by the mecAgene in $S$. aureus MRSA stabilizes the cell wall formation and showed resistant towards $\beta$-lactam antibiotics by blocking the interaction between $\beta$-lactam and penicillin-binding protein (PBP)(Fig. 2) (Mun et al., 2014). However, a combination of $\beta$-lactam antibiotics with curcumin inhibits Mec A gene synthesis in MRSA and enhances the activity of antibiotics (Mun et al., 2014). It is reported that polymeric micelles coated silver particles with curcumin molecules were very effective against Staphylococcus aureus and $P$. aeruginosa (Huang et al., 2017). In chicken and mice curcumin was effective in kidney and liver injury caused by aflatoxin induction (Verma et al., 2008; Zhang et al., 2016) and minimized the effect of oxidative stress (mediated by aflatoxins) (Wang et al., 2018). Furthermore, the formulation of curcumin loaded PLGA nanoparticles improved the activity of curcumin; PLGA is hydrolyzed into lactic acid and glycolic acid and eliminated outside the cell in the form of $\mathrm{H}_{2} \mathrm{O}$ and $\mathrm{CO}_{2}$ with the help of the Krebs cycle (Lu et al., 2009).

\section{Anti-biofilm activity}

Curcumin inhibits the quorum sensing and acts as an inhibitor of biofilm formation (Deryabin et al., 2019). Pseudomonas aeruginosa secreted exopolysaccharides polymer substances e.g., imipenem and aminoglycosides, which enhanced biofilm formation. Curcumin's anti-biofilm activity against two Pseudomonas aeruginosa strains obtained by cystic fibrosis suffering patients were observed with MIC: $16 \mu \mathrm{g} / \mathrm{m}$ through the crystal violet staining method (Karaman et al., 2013). It is found that curcumin inhibits the expression of biofilm inducing gene (31 quorum sensing (QS) genes) reducing virulence factors such as acyl-homoserine lactone (HSL) secretion, pyrocyanin biosynthesis, and activity of protease (Rudrappa and Bais, 2008). In S. mutans, UA159 curcumin could reduce biofilm activity and prevent the maturation of biofilm by exopolysaccharide reduction (Li et al., 2018).

\section{Anti-protozoan activity}

Ethanol extraction of turmeric (rhizome) has antiEntamoeba histolytica activity. It also shows antiLeishmania activity in vitro conditions (Koide et al., 2002). Curcumin synthetic derivatives have antiLeishmania, amazonensis activities (Gomes et al., 2002). Rasmussen et al., reported that curcumin also inhibits the activity of Plasmodium falciparum (Rasmussen et al., 2000).

\section{Antioxidant activity}

Curcumin has excellent antioxidant activity (Alsamydai and Jaber, 2018). Harmful chemicals, trauma, autoimmune disorders, and infections can be responsible 


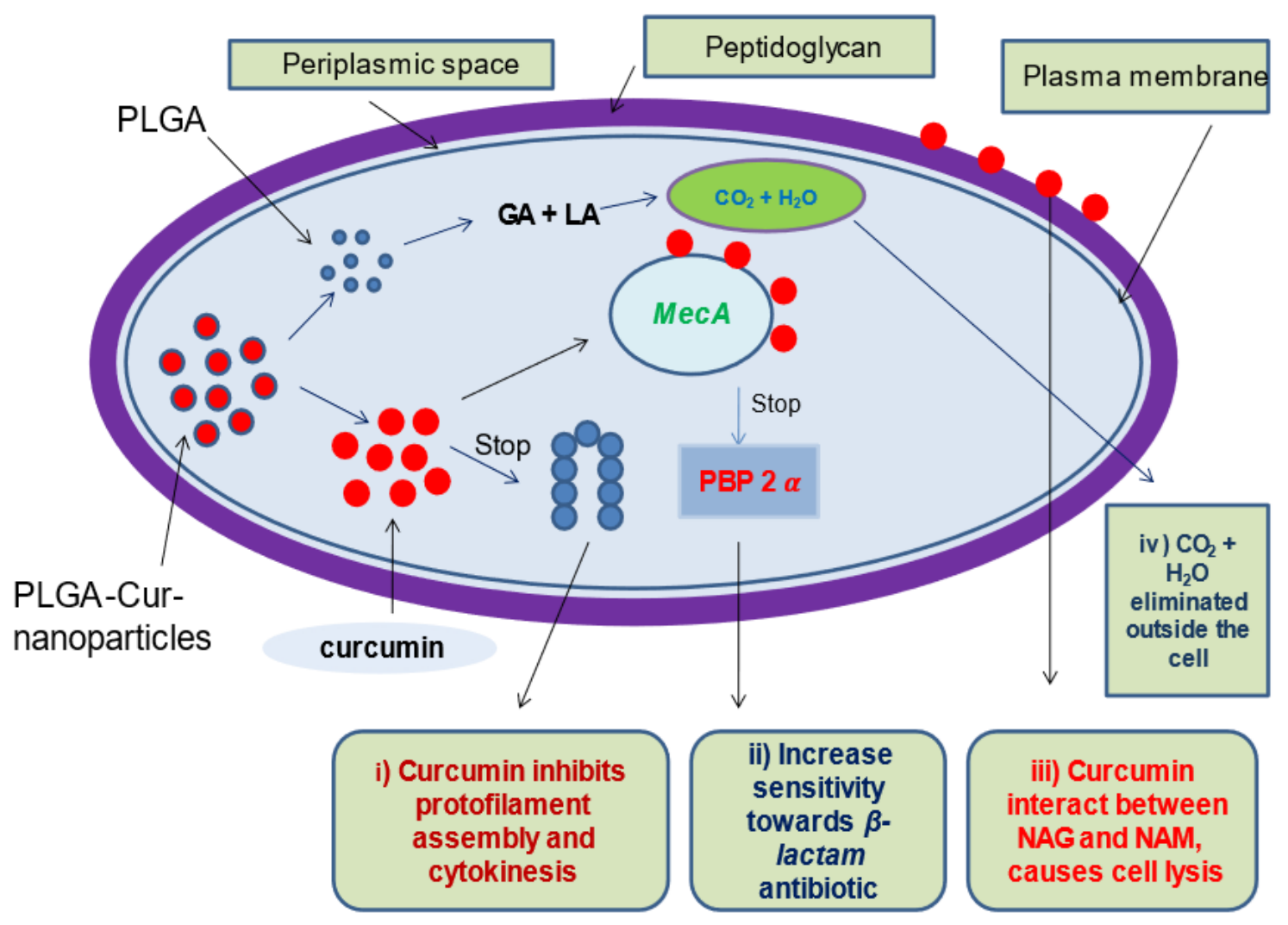

Fig. 2. Diagrammatic representation of various mode of actions of PLGA curcumin nanoparticles against Gram positive pathogens (a) Curcumin inhibits protofilament assembly and cytokinesis (Rai et al., 2008) (b) Curcumin increase sensitivity towards $\beta$-lactam antibiotic (Mun et al., 2014) (c) Curcumin interact between NAG and NAM, causes cell lysis (Mun et al., 2014, Tyagi et al., 2015) (d) Gylcolic acid and Lactic acid eliminate outside the cell in the form of $\mathrm{CO}_{2}+\mathrm{H}_{2} \mathrm{O}(\mathrm{Lu}$ et al., 2009).

for the production of free radicals in the body, curcumin has capacity to protect the cells from free radicals and work as a scavenger for reactive oxygen species (Akram et al., 2010). Curcumin is a bioactive component of turmeric (Kotha and Luthria, 2019), turmeric's water-and-fat-soluble extracts show potent antioxidant activity like vitamin $C$, vitamin $E$, and $\beta$ carotene (Akram et al., 2010). Curcumin significantly inhibits the peroxidation of lipids in various animal models (Maheshwari et al., 2006). Metabolism of lipoxygenase (LOX), arachidonic acid, and cyclooxygenase (COX) inhibited by the curcumin, which alters the productions of steroidal hormones (Mosovska et al., 2016). Researchers have investigated the antioxidant property of curcumin in animal cells by exposing the oxygen and nitrogen-free radical species and concluded the antioxidant efficacy of curcumin (Rafiee et al., 2019).

\section{Anti-inflammatory activity}

A secondary metabolite of curcumin and its volatile oils show great anti-inflammatory activity, $100 \mathrm{mg} / \mathrm{kg}$ of eth- anol extracted turmeric component is significantly administered to male rats in the granuloma pouch model and showed great activity against inflammation. In induced pedal edema doses of $200 \mathrm{mg} / \mathrm{kg}, 400 \mathrm{mg} / \mathrm{kg}$, and $800 \mathrm{mg} / \mathrm{kg}$ were active in carrageen. However, turmeric extract showed no activity in the granuloma pouch model when reducing the dose to $50.0 \mathrm{mg} / \mathrm{kg}$ (Bhat et al., 2015). Several studies have reported that curcumin inactivates the process of inflammation through various mechanism (Khalil and Mustafa, 2020; Mohammed and Mustafa, 2020). In the case of acute inflammation, oral curcumin was more effective compared to phenylbutazone or cortisone and reduced inflammatory swelling in rats with Freund's adjuvant-induced arthritis. Curcumin is also effective in neutrophil aggregation related to inflammation, in monkeys, at the time of inflammation, it inhibits the biosynthesis of inflammatory prostaglandins and arachidonic acid (Akram et al., 2010). Curcumin Nanomicelle particles had more anti-inflammatory efficacy to inhibit paraquat (PQ) responsible for lung injury (Hosseini et al., 2019). 


\begin{abstract}
Anti-carcinogenic activity
Curcumin exhibits anti-carcinogenic properties which act as a panacea for the treatment of various types of cancers in human curcumin inhibits tumor growth and proliferation of cells; it is also capable of suppressing the mutagens and carcinogen's activity in different types of cells (in vitro and in vivo) (Akram et al., 2010). Curcumin molecule alter the activity of NF-kB factors responsible for the activation of gene related to proliferation, antiapoptotic and invasion (Tan and Norhaizan, 2019). Due to antioxidant and free-radical engulfing properties, curcumin shows anti-carcinogenic activity. It indirectly increases the level of glutathione that helps in liver detoxification from harmful carcinogens and mutagens as well as stops the synthesis of nitrosamine (Akram et al., 2010). Curcumin is a very potent agent for controlling and regulating the metabolic activation and detoxification of harmful mutagens and carcinogens. Curcumin inhibits the action of cytochrome P450 and this enzyme stimulates the action of carcinogens and mutagen (Duvoix et al., 2005). In lung and breast cell lines PLGA curcumin nanoparticles reduced the expression of NF-kB and HIF-1 $\alpha$ in the hypoxic tumor microenvironment (Khan et al., 2018). Curcumin enhances metabolizing enzymes and antioxidant activity (Igbal et al., 2003). Curcuminoid exhibits several immunomodulatory effects (Churchill et al., 2000), suppresses the production of superoxide (free radicals) by macrophages and also enhances phagocytic activity of macrophages observed in the curcumin-treated animal model (Lukita-Atmadja et al., 2002).
\end{abstract}

\section{TARGETED VS. COMBINATIONAL DRUG THERAPY AGAINST GRAM-POSITIVE PATHOGENS}

Instead of broad-spectrum antibiotics, narrow-spectrum antibiotics, or targeted antibiotics that are specific for particular pathogenic bacteria either Gram-positive or Gram-negative provides an efficient approach to treat specific resistant pathogens with a less toxic effect on the gut microbiome (Maxson and Mitchell, 2016). Different types of synthetic targeted antibiotic therapies are available against Gram-positive pathogens such as Linezolid, Vancomycin, Teicoplanin, Daptomycin, Tigecycline, and Ceftaroline (Guillamet and Kollef, 2014). Over the targeted antibiotic therapy, combinational drug therapy is an appropriate method for treating multidrug-resistant (MDR) bacteria. Three main mechanisms of antibiotic resistance are described by Walsh in 2000: (i) enzymatic breakdown of $\beta$-lactam antibiotics with the help of $\beta$-lactamases enzymes and phosphorylation or acetylation, adenylation of aminoglycosides (ii) Antibiotic removal from the bacterial cell, through the efflux membrane-bound protein, efflux membrane proteins force out the drug molecules faster than its diffusion hence, decreasing the overall intracel- lular concentration of antibiotics required to exert the antibiotic effect (iii) Modification of penicillin- binding protein (PBP2a) by the bacteria, PBPs have a lower affinity to $\beta$-lactam antibiotics resulted in continuous cell wall synthesis (Worthington and Melander, 2013). In combined drug therapy pairing is done between antibiotic- antibiotic or antibiotic with a non-antibiotic molecule. The combinations of two drugs have a synergistic effect, enhanced killing rate, and increased dosage response in in vivo settings (Bhardwaj et al., 2016). Researchers have found that combined drug therapy of curcumin and chemotherapeutics have pharmaceutical activity and also reported their mode of action in vitro and in vivo (Redondo-Blanco et al. 2017). The naturally occurring substance used for combination therapy with antibiotics is the most beneficial approach for MDR bacteria. Combinational effect of curcumin with various antibiotics on $S$. aureus by disk diffusion method and found that curcumin increased the antibacterial activities of antibiotics cefotaxime, cefixime, tetracycline, and vancomycin against $S$. aureus. Although cefixime showed the maximum fold increases in the area $(52.6 \%$ fold increase) against test strain (Worthington and Melander, 2013). In combinational drug therapy, the interaction of two antimicrobial agents is an important factor for the formulation hence, at the time of drug development this factor must be taken into consideration (Moghaddam et al., 2009). Zhang et al., 2020 reported efficacy of chemotherapy medicine and various plant extract such as xanthohumol, curcumin, genistein, proanthocyanidins, mangiferin, luteolin, quercetin, garcinol, and furanodiene against breast cancer and their mechanisms in vivo and in vitro condition. Combinational drug therapy is the most powerful tool for the treatment of various critical diseases like HIV (Richman, 2001), cancer, and antibiotic-resistant infections (Lane 2006, Mitchison and Davies 2012, Fischbach 2011). In a study reported that when paclitaxel combined with curcumin greatly stimulate apoptosis process and antiproliferative in MCF-7 and MDA-MB231 (human breast cell lines) (Calaf et al., 2018; Kang et al., 2009; Quispe et al., 2016; Zhan et al., 2014). Combined effect of natural plant products have more potential to fight against breast cancer cells as compare to single plant extract (Kapinova et al. 2017; Koh and Pan 2018). Combinational drug therapy is an alternative approach for the treatment of multi and extremely drug-resistant bacterial infections.

\section{THERAPEUTIC APPLICATIONS OF NANO- PARTCLES}

Nanoparticles are used in different areas successfully due to their high volume-surface ratio and quantum effects; these factors change the nanoparticle proper- 
ties such as electrical behavior, reactivity, strength, and in vivo nature. Nanoparticles have been used to develop much cheaper, effective, and quicker treatments against pathogens (Duggal, 2011). Previous studies have demonstrated that nanoparticles such as Ag-NPs, TiO2-NPs, and ZnO-NPs (used for sewage treatment) may show the toxic effect on aquatic organisms (Gottschalk et al., 2009), while gold, silver, and copper nanoparticles have the great anticancer potential (Jain et. al., 2012, Jannathul and Lalitha 2015, Sanpui et. al., 2011). Gold nanoparticles showed optical and catalytic properties which makes it unique due to its biocompatible and nontoxic in nature and used in various fields (Nambiar et al., 2018). Anticancer and antidiabetic activities of ZnO-NP have been reported by a group (Umrani and Paknikar 2014, Taccola et al., 2011). CUR -SF (curcumin silk fibroin) nanoparticles are effective and stable drug delivery agent and exhibit anticancer effect against intestinal colon cancer than native curcumin (Xie et al., 2017). The anti-cancer activity may involve in DNA repair, cell proliferation, cell differentiation, angiogenesis, progression and carcinogen metabolism (Rejhova et al., 2018; Singh et al., 2016). Green synthesis of metal nanoparticles has shown beneficial effects due to their less toxicity, cheap and eco-friendly properties compare to other chemical methods (Makarov et al., 2014), synthesis of nanoparticles by the microorganisms have been reported as environmental-friendly alternatives over physical and chemical methods (Makarov et al., 2014). Green synthesis of gold nanoparticles (AuNP's-Cur) observed in HCT116 and MCF-7 (breast cancer cell lines). Results suggested that AuNP's-Cur effectively reduce apoptotic and proliferation effect in cancer cells compared to curcumin molecule (Elbialy et al., 2019). Similarly, it was suggested that MNP-PEG-Cur nanoparticles (magnetic nanoparticle ornamented with PEGylated curcumin) were good biocompatible drug delivery agent for antitumor drugs (Ayubi et al., 2019). Nambiar et al., 2018 reported that gold nanoparticles formulated together with the plant products had diverse applications in biomedical fields. Polymeric nanoparticles are made up of a long number of repeating units (macromolecules) and arrange in a series showing unique properties and structure, which is useful in biomedical applications (Jain, 2008). Nanoparticles can be successfully used in targeted drug delivery at the site of infection to improve (Duggal, 2011): bioavailability of the drug, successful uptake of less soluble drugs, and targeting of the drug at an appropriate site. Duggal, also reported that nanoparticles possess various kinds of advantages: Enhanced bioavailability potential, reduced toxicity, small amount requirement, and increased surface area of the active agent (Duggal, 2011). Besides metal nanoparticles, polymerbased nanospheres have been made which possess several advantages such as easy to synthesize, costeffective, biocompatible, biodegradable, nontoxic, soluble in water, non-immunogenic (Bolhassani et al., 2014).

Polymeric nanoparticles that are classified (in vivo) as biodegradable are Poly-glycolide (PGA) (Park et al., 2009), Poly (L-lactide) (PLA) (Mainardes et. al., 2010) and non-biodegradable like polyurethane (FritzenGarcia et al., 2009). PEG-albumin-curcumin (PAC) nanoparticles exhibits greater anticancer activity against breast cancer cell line due to more bioavailability and long-time stability in blood circulation (Thadakapally et al., 2016). Characteristics of nanoparticles like strength, performance, flexibility, chemical, and physical behaviour advocate their use in pharmaceutical industries and medicine such as: in drug delivery, tumour detection as well as visual monitoring of therapy (Gwinn and Vallyathan, 2006). Different types of nanoparticles and their roles are described in Table 1.

\section{FORMULATION OF CURCUMIN NANOPARTICLES}

The studies from the last three decades showed that curcumin exhibits poor absorption, reduced bioavailability, poor metabolism, elimination, and rapid degradation (Krausz et al., 2015). Therefore, to overcome these problems, it is necessary to design an advanced drug delivery system that can enhance the therapeutic translation of curcumin. Chauhan et al., 2014 reported different drug delivery systems like liposome (formulation of curcumin for parenteral administration). Liposome exhibits several properties like high stability, better solubility, high biocompatibility and easy preparation (Moballegh Nasery et al., 2020), nanoparticles (polymeric and solid lipid NPs), and microemulsion (Bansal et al., 2011, Maiti et al., 2007). Polymeric nanoparticles have features like biocompatible, small in size and stay in bloodstream for longer time (Ferrari et al., 2018). Roacho-Perez et al., 2020 reported that magnetic nanoparticles are of low synthesis cost and highly responsive for cancer treatments. Curcuminnanoparticles are probably the most effective approach for the therapeutic application of curcumin. In this review, we have focused on the formulations of curcumin loaded poly (lactic-co-glycolic) acid (PLGA) nanoparticles and its efficacy against different types of human pathogens. There are several methods for the synthesis of curcumin loaded PLGA nanoparticles (PLGA-curNPs). We have discussed all the methods, including the positive and negative aspects of techniques used as below:

\section{Coacervation method}

In this method, the polymer is dissolved in ethyl acetate, dichloromethane, or acetonitrile (organic solvent) and curcumin molecules directly suspended within the 
Sankhwar, R. et al. / J. Appl. \& Nat. Sci. 13(1): 110 - 126 (2021)

Table 1. Various compounds used for the formation of nanoparticles and their diverse role and applications.

\begin{tabular}{|c|c|c|}
\hline $\begin{array}{l}\text { Compounds used for } \\
\text { Nano-formulation }\end{array}$ & Applications & Reference \\
\hline Silver & $\begin{array}{l}\text { Antimicrobial, antiviral activity and } \\
\text { used in textile industries, water treatment, and } \\
\text { sunscreen lotions etc. }\end{array}$ & $\begin{array}{l}\text { Rai, Yadav and Gade, 2009, Shar- } \\
\text { ma, Ria and Lin, } 2009\end{array}$ \\
\hline Gold & $\begin{array}{l}\text { Used in the identification of protein interactions, } \\
\text { detect cancer stem cells, beneficial for cancer } \\
\text { diagnosis, and identification of different classes } \\
\text { of bacteria. }\end{array}$ & $\begin{array}{l}\text { Baban and Seymour, 1998, Tomar } \\
\text { and Garg, } 2013\end{array}$ \\
\hline Magnet & $\begin{array}{l}\mathrm{Fe}_{3} \mathrm{O}_{4} \text { (Magnetite) and } \mathrm{Fe}_{2} \mathrm{O}_{3} \text { (maghemite) both } \\
\text { are biocompatible NPs, used in manipulation, } \\
\text { stem cell sorting, guided drug delivery system, } \\
\text { magnetic resonance imaging (MRI), gene thera- } \\
\text { py, and DNA analysis. }\end{array}$ & Fan, Chow and Zhang, 2009 \\
\hline Copper & $\begin{array}{l}\text { Copper NPs are DNA-cleavage agents, efficient } \\
\text { anticancer, and modifiable surface properties by } \\
\text { conjugation with various biomolecules including } \\
\text { proteins and enzymes. }\end{array}$ & $\begin{array}{l}\text { Fang et al., 2010, Thanh and } \\
\text { Green, 2010, Wang et al., 2015, } \\
\text { An and Zhang } 2017 \text {. }\end{array}$ \\
\hline Polyethylenimine (PEI) & $\begin{array}{l}\text { PEI (cationic polymer) used for nucleic acid deliv- } \\
\text { ery, immune dysfunction, cancers and allergy. }\end{array}$ & $\begin{array}{l}\text { Saengkrit et al., 2012, Nguyen and } \\
\text { Friedman, } 2013\end{array}$ \\
\hline Poly- $£$ - caprolactone (PCL) & $\begin{array}{l}\mathrm{PCL} \text { is used for the development of contraceptive } \\
\text { devices, wound dressings, drug delivery systems } \\
\text { as well as fixation devices. }\end{array}$ & Bilensoy et al., 2009 \\
\hline Polyacrylate & $\begin{array}{l}\text { Antibiotic-conjugated Polyacrylate nanoparticles } \\
\text { are used as antimicrobial agents. }\end{array}$ & Turos et al., 2007 \\
\hline A-----lbumin & $\begin{array}{l}\text { This is used for the delivery of protein, oligonu- } \\
\text { cleotides, DNA as well as drugs. }\end{array}$ & $\begin{array}{l}\text { Moreno-Vega et al., 2012, Bolhas- } \\
\text { sani et al., } 2014\end{array}$ \\
\hline Heparin & $\begin{array}{l}\text { Used for the delivery of oligonucleotides, DNA, } \\
\text { protein, and drugs. }\end{array}$ & $\begin{array}{l}\text { Moreno-Vega et al., 2012, Bolhas- } \\
\text { sani et al., } 2014\end{array}$ \\
\hline Chitosan & Used as a carrier of DNA for gene delivery. & Nguyen et al., 2009 \\
\hline $\begin{array}{l}\text { Poly(lactic- co-glycolic acid) } \\
\text { (PLGA) }\end{array}$ & $\begin{array}{l}\text { Used as drug release devices, implants to repair } \\
\text { fractures, and surgical sutures. }\end{array}$ & $\begin{array}{l}\text { Xiaoling and Haskara 2006, Steva- } \\
\text { novic and Skokovic 2009, Steva- } \\
\text { novic et al., } 2008 .\end{array}$ \\
\hline
\end{tabular}

polymeric solution and then leave it to homogenize. High-speed centrifugation is employed for Nanoparticles collection. The disadvantage of this method is that it requires more solvent (Dhivya and Rajalakshmi, 2018).

\section{Single emulsion method}

Curcumin NPs are synthesized by dispersing it in a solvent, by ultrasonication or high-speed homogenization to form the emulsion. The solvent evaporated from the emulsion by continuous magnetic stirring under reduced pressure at room temperature. After this, step the emulsion is ultrasonicated then collected, washed (distilled $\mathrm{H}_{2} \mathrm{O}$ ) to remove additives and allow to lyophilized to create nanoparticles. Curcumin loaded PLGA nanoparticles can also be prepared by the Single emulsion method (Dhivya and Rajalakshmi 2018).

\section{Solvent evaporation method}

Two steps involve in the Solvent Evaporation Method (i) Solution of drug-polymer preparation step (ii) dispersing solvent evaporation, and this step helps curcu- 
min to dissolve properly. Formation of emulsion that changed into nanoparticle suspension followed by a solvent evaporation process. The advantages and disadvantages of this method are: (i) for evaporation of solvent required low temperature (ii) prevention of thermal deposition can occur. (i) difficulty in the selection of solvent (ii) it is a time-consuming process due to evaporation of the organic solvent (iii) in this method expensive reagents used. PLGA (Poly (lactic acid-co-glycolic acid) curcumin nanoparticles can be formulated by this method (Dhivya and Rajalakshmi 2018).

\section{Solvent displacement method}

This method, also called the Nanoprecipitation method, within a suitable solvent a particular polymer is suspended which results in the formation of a polymeric solution. Add natural drug-like curcumin into it. A drugpolymer combination solution is poured into the $\mathrm{H}_{2} \mathrm{O}$ by stirring it without interruption after some time gets precipitation. Then left solvent for evaporation by hot airflow. Formation of nano-drugs in the amorphous state by the spray drying method may lead to partial crystallization. In this, polymer and curcumin are dissolved in the same mixture of solvents (Dhivya and Rajalakshmi 2018).

\section{Solvent evaporation method (Solid-in-oil-in-water emulsion; s/o/w)}

In this method, PLGA dissolved in chloroform (organic solution) as an oil phase. Free curcumin is added to the PLGA or chloroform solution and after this emulsion is added to a solution of ethanol and PVA (Polyvinyl alcohol) and sonicated. For removing the organic phase (evaporation) of solvent (chloroform) s/o/w emulsion agitated by stirrer. The sample is then centrifuged and washed three times with distilled water. After this, sample is freeze-dried for $24 \mathrm{hrs}$ to obtain nanoparticle dry powder. The nanoparticles are stored at $4{ }^{\circ} \mathrm{C}$ for further use (Mukerjee and Vishwantha 2009, Nair et al., 2012).

\section{Single emulsion-solvent evaporation method}

This method is suitable for loading curcumin (a hydrophobic compound) in hydrophilic solvent, PLGAcurcumin nanoparticles can be formed (Cartiera et al., 2010). In the desired amount of ethyl acetate, PLGA polymer dissolved into it after this step drug (curcumin) added to this mixture and for left 30 minutes for complete dissolution (intermittent vortexing). Then Poly (vinyl alcohol) (PVA) is mixed in $\mathrm{H}_{2} \mathrm{O}$ that act as a surfactant after this step mixture of curcumin PLGA added into it drop-wise with intermittent vortexing. The mixture is sonicated to create a fine emulsion. Then this emulsion is added to PVA in $\mathrm{H}_{2} \mathrm{O}$ and stirred rapidly with a magnetic stirrer for about 3 hours. PVA helps in stabilizing the emulsion and small particles with uniform size are formed. The nanoparticles are collected by centrifugation and washed three times with Milli-Q distilled water. Then at $4{ }^{\circ} \mathrm{C}$ freeze-dried nanoparticles are stored (Mathew et al., 2012).

\section{Double-emulsion or single-emulsion with vitamin e-tpgs}

Recently Rebecca et al., used vitamin E-D- $\beta$ Tocopherol polyethylene glycol succinate (TPGS) as the emulsifying agent. The major advantage of using TPGS is that it improves emulsification and encapsulation efficiency compared to other emulsifying agents. In a test tube, $100 \mathrm{mg}$ PLGA, and $1 \mathrm{ml}$ of dichloromethane (DCM) or ethyl acetate (EtAc) solvent added in it. Then, $2 \mathrm{ml}$ of 0.3 vitamins E-TPGS is added to the glass test tube. For hydrophobic substances: encapsulant added to the polymer solution directly, then vortex the test tube until encapsulant is homogenously spread over a wide area (dispersed). For hydrophilic substances: the polymer solution with emulsify encapsulant added before starting the addition of drug in buffer or $\mathrm{H}_{2} \mathrm{O}$ to the polymeric solution. For emulsification, the polymer and the drug combination ultrasonicated for some time. The polymer solution directly dropped onto the surface of the emulsifier with continuous vortexing. Immediately, the emulsified polymer is ultrasonicated that forms the nanoparticles in the precipitation, and allow the solvent to evaporate (McCall and Sirianni, 2013).

\section{APPLICATION OF PLGA-CURCUMIN NANO PARTICLES}

Curcumin is a pleiotropic phytonutrient exhibit number of therapeutic properties, but their optimum potential is hindered by poor solubility, low oral bioavailability, insufficient water solubility leading to low absorption and rapid degradation. To overcome these drawbacks nano vehicles like the drug delivery system were investigated such as curcumin loaded PLGA (polylactide- coglycolide) nanoparticles for its better activity and bioavailability for cellular absorption (Anand et al., 2010). A study showed that curcumin obtained by the heat extraction method increases the solubility of curcumin 12fold without any degradation (Kurien et al., 2007). Similarly, nanoformulation enhance the therapeutic and biological applications of curcumin molecules (Karthikeyan et al., 2020). Another study found that curcumin nanoparticles size ranges between 2- $40 \mathrm{~nm}$ prepared by the wet-milling technique have a small size, large surface area, and increased bioavailability. These curcumin NPs are more easily dispersed in water as compared to the curcumin without any formulation and show more effective antimicrobial activity against Escherichia coli, Bacillus subtilis, Staphylococ- 
Curcumin + PLGA<smiles>C=C=C</smiles>

Curcumin loaded PLGAnanoparticles<smiles>C=[Ge]</smiles>

CurcumirPLGAnanoparticles enter inside bacterial cell

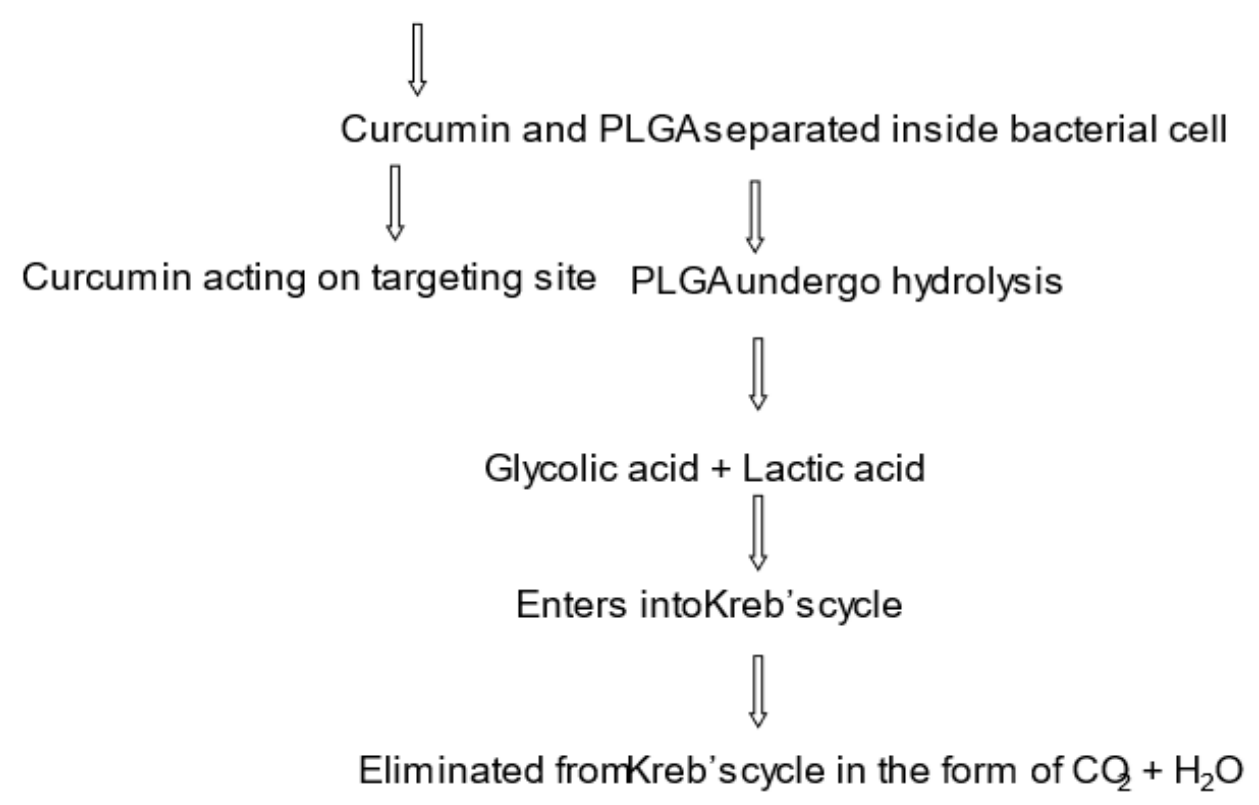

Fig. 3. Representation of formation of PLGA curcumin nanoparticles and its fate within the living cells (Lu et al., 2009).

cus aureus, Pseudomonas aeruginosa, and two known pathogenic fungi Penicillium notatum and Aspergillus niger (Bhawana et al., 2011, Shailendiran et al., 2011). Recently, it was reported that PLGA curcumin nanoparticles suppress the NF-kB signaling in mammary glands infected by Staphylococcus aureus. Thus, curcumin nanoparticles are also beneficial for murine mastitis (Suresh et al., 2018). Curcumin stability can be enhanced by the micro-encapsulation method which improves the bioavailability and solubility of curcumin and also shows antimicrobial activity against various foodborne pathogens (MIC ranges between $15.7 \mu \mathrm{g} / \mathrm{mL}$ to $250 \mu \mathrm{g} / \mathrm{mL}$ ), e.g. Escherichia coli, Staphylococcus aureus, Bacillus subtilis, Yersinia enterocolitica and Penicillium notatam. This suggests that microencapsulated curcumin particles can be used as a food preservative and colourant in food industries (Wang et al., 2009, Wang et al., 2012).

In the present time, one of the most useful applications of curcumin loaded PLGA nanoparticles are in the treatment of different types of human cancer (Mukerjee and Vishwantha, 2009), which is less toxic due to their degradative nature compare to other drugs (Dauda et al., 2017). All these studies suggest that the broadspectrum activity of this golden spice (turmeric) is suc- cessfully enhanced by curcumin loaded PLGA nanoparticles. Curcumin is a hydrophobic molecule that possesses miracle biological activities. Poly (lactic-coglycolic acid) is one of the most important biodegradable and bioabsorbable polymer which is eliminated by the body itself (Stevanovicet al., 2009). The PLGA polymers are also used as surgical sutures, fracture repair, and medical devices (Xiaoling and Haskara, 2006). PLGA has ester linkages that give hydrolysis reaction in water and forms two monomers glycolic acid and lactic acid which are metabolized and eliminated through the Kreb's cycle as $\mathrm{H}_{2} \mathrm{O}+\mathrm{CO}_{2}$ (Fig. 3) ( $\mathrm{Lu} \mathrm{et}$ al., 2009).

A variety of antibiotics are used for the treatment as well as prevention of bacterial infections but due to improper use of antibiotics, the emergence of multi-drug resistant strain is a big challenge (Ayukekbong Ntemgwa and Atabe, 2017). Naturally occurring molecules have an excellent opportunity for the development of new therapeutic, which can be effective against various resistant pathogens. Curcumin is a natural compound extracted from turmeric rhizome, it is hydrophobic, and a pleiotropic molecule that gives the yellow color to the turmeric and exhibits different types of therapeutic activities (Allam, 2009, Magalhaes et al., 2009). 
Several antimicrobial activities of curcumin have been reported by a group of scientists (Bhawana et al., 2011; Tongnuanchan and Benjakul, 2014) and demonstrated that the turmeric component stopped the activity of $S$. aureus and $E$. coli. The methanolic extract of turmeric exhibited strong antimicrobial activity (Alcaraz et al., 2000, Niamsa and Sittiwet, 2009). Curcumin also shows anti-inflammatory, wound-healing, hypoglycemic, and antioxidant properties as well as induce apoptosis in different types of cells (Aggarwal, Sung 2009, Akram et al., 2010). Moreover, curcumin has several types of therapeutic activities like anticancer and have great potency to reduce the proliferation of cells, metastasis of tumor cells, and transformation(Nakamura et al., 2002, Shishodia et al., 2007). Curcumin also shows the good chemoprotective agent in cancer therapy(Duvoix et al., 2005). Anti-MRSA activity of curcumin sensitizing methicillin-resistant Stayphylococcus aureus (MRSA) against various antibiotics (Mun et al., 2014). Instead of this, curcumin has a property to cure different eye-related problems like inflammation of the eye, red eye condition, pain, and loss of vision. Research has shown that curcumin was effective against uveitis disease when $600 \mathrm{mg}$ dose was orally given to the 106 patients twice a day for 12 to 18 months. After a treatment within a few weeks, more than $80 \%$ of the patients were relieved from eye abnormalities (Allegri, Mastromarino and Neri, 2010). Turmeric's main component curcumin that is potent antioxidant substances like beta-carotene, vitamins $E$ and $C$ are used for cancer and liver diseases as well as an anti-ageing agent. Besides, curcumin also eases back pain, arthritis, and bursitis by their anti-inflammatory property(Akramet al., 2010). Three different properties of curcumin act together and responsible for the anti-inflammatory action: (i) curcumin reduces the production of inflammatory molecules such as histamine (ii) curcumin enhances the secretion of natural anti-inflammatory hormone (adrenal and cortisol) that increases the blood circulation and eliminate the toxic substance from the body (III) research also confirmed that curcumin also promotes the flow of bile juice by the gall bladder and finally increases the digestion of fat and eliminate toxic/ waste materials outside the body (Akram et al., 2010). Curcumin's antioxidant and anti-inflammatory properties (Surh et al., 2001) minimize the lipid peroxidation and prevents cardiovascular diseases (Smerak et al., 2006).

Curcumin displays broad-spectrum therapeutic activities, but due to its low oral bioavailability, rapid degradation, and poor water solubility, it could not make a clinical impact (Sharma et al., 2007). Curcumin nanoparticles enhance bioavailability (Muqbil et al., 2011). It has been reported that particle size plays an important role in enhancing cellular uptake, absorption, physical stability, and drug release from the nano surface (Feng, 2004). Different types of nanocarriers have been used in drug delivery systems like liposome, solid lipids nanospheres, silicon or carbon as well as dendrimers, etc. (Karuppusamy and Venkatesan, 2017). PLGA is an important biodegradable polymer used in nanomedicine as a drug delivery vehicle, and hydrolysis results in the formation of glycolic acid and lactic acid, metabolized in Kreb's cycle and eliminated as $\mathrm{CO}_{2}$ and $\mathrm{H}_{2} \mathrm{O}$ from the body. PLGA is used as a drug delivery system in humans approved by the European Medicine Agency and US FDA (Mirakabad et al., 2014). Curcumin loaded PLGA nanoparticles exhibited schistosomicidal activity, at the concentration of 50 and $100 \mu \mathrm{M}, 100 \%$ death of parasites caused by these particles at $120 \mathrm{hrs}$ (Luz et al., 2012). Yallapu et al., reported that curcumin loaded nanoparticles effective against ovarian cancer (Yallapu et al., 2010). Curcumin-nanoparticles inhibited first stage metastasis, hence can be used in the cancer treatment (Bisht et al., 2007).

\section{Conclusion}

In the present review article, we have explored the characteristics of curcumin, variety of functions, various nano-curcumin formulation methods, their pros and cons, and the importance of PLGA-nano curcumin against pathogenic bacteria. Curcumin is nontoxic and has great therapeutic roles like antimicrobial, antioxidant, anti-inflammatory, anti-cancerous, anticholesterol, and antidiabetic as well as shows hepatoprotective, neuronal protective, immune enhancer, cardiovascular and gastrointestinal effects. Curcumin nanoparticles have immense importance in therapeutics and can be used in combinatorial drug therapy such as (I) PLGA-curcumin-nanoparticles combined with first-line antibiotics (amoxicillin, erythromycin, etc) may be effective against multidrugresistant bacteria. (II) formulation of broad-spectrum antibiotic products that stop the growth of Grampositive and Gram-negative bacterial infections. (III) formulation of curcumin-based ointment or gel for wound healing and skin infections. Besides this, curcumin may also be effective for crop productivity, and when mixed with soil, it increases the fertility of the soil. Curcumin's antioxidant property is the most important feature, which makes it more powerful as well as increases its therapeutic importance against lifethreatening illnesses like AIDS, cancer, tumor, cardiovascular diseases, and lifestyle diseases such as diabetes. Almost all the aspects of curcumin, its role, and applications in therapeutics, emphasizing the antimicrobial properties against Gram-positive pathogens and the use of PLGA-curcumin nanoparticles in combinatorial drug therapy against resistant bacterial 
strains which is the prominent necessity of the present time, especially in developing countries have been discussed.

\section{ACKNOWLEDGEMENTS}

The authors would like to thank the Department of Microbiology, Babasaheb Bhimrao Ambedkar University, Lucknow for providing basic infrastructure support. RG was supported by the UGC-BSR start-up grant Programme. RS and AK were supported by the research stipend from the Babasaheb Bhimrao Ambedkar University (A Central University), Vidya Vihar, Raebareli Road, Lucknow-226025.

\section{Conflict of interest}

The authors declare that they have no conflict of interest.

\section{REFERENCES}

1. Ayubi, M., Karimi, M., Abdpour, S., Rostamizadeh, K. Parsa, M., Zamani, M. \& Saedi, A. (2019). Magnetic nanoparticles decorated with PEGylated curcumin as dual targeted drug delivery: Synthesis, toxicity and biocompatibility study. Materials Science and Engineering C: Materials for Biological Applications. 104,109810. DOI: 10.1016/ j.msec.2019.109810.

2. Ayukekbong, J.A., Ntemgwa, M. \& Atabe, A.N. (2017). The threat of antimicrobial resistance in developing countries: causes and control strategies. Antimicrobial Resistant and Infection Control. 6,47.doi.o rg/10.1186/s13756-017-0208-x.

3. Akbik, D., Ghadiri, M., Chrzanowski, W. \& Rohanizadeh R. (2014). "Curcumin as a wound healing agent." Life Sciences.116,1-7.doi.org/10.1016/j.lfs.2014.08.016.

4. Arun, N. \& Nalini, N. (2002). Efficacy of turmeric on blood glucose and polyol pathway in diabetic albino rats. Plant Foods for Human Nutrition.57,41-52.doi.org/ 10.1023/ a:1013106527829.

5. Aggarwal, B.B., Bhatt, I.B., Ichikawa, H., Ahn, K.S., Sethi, G., Sandur, S.K., Natarajan, C., Seeram, N. \& Shishodia, S. (2007), Curcumin biological and medicinal properties. In Turmeric: The Genus Curcuma, Ravindran PN, NirmalBabu K, Sivaraman K, Eds. CRC Press: New York. 297368.

6. Akram, M., Uddin, S., Ahmed, A., Khan, U., Hannan, A., Mohiuddin, E. \& Asif, M. (2010). Curcuma longa and curcumin: A review article. Romanian Journal of BiologyPlant Biology. 55,65-70.

7. Anand, P., Nair, H.B., Sung, B., Kunnumakkara, A.B., Yadav, V.R., Tekmal, R.R. \& Aggarwal, B.B.(2010). "Design of curcumin-loaded PLGA nanoparticles formulation with enhanced cellular uptake, and increased bioactivity in vitro and superior bioavailability in vivo," Biochemical Pharmacology.79,330-338.https://doi.org/10.1016/ j.bcp.2009.09.003.

8. Allegri, P., Mastromarino, A. \& Neri, P. (2010). Management of chronic anterior uveitis relapses: efficacy of oral phospholipidic curcumin treatment. Long-term follow-up.
Clinical Ophthalmology,21,1201-1206.doi.org/10.2147/ OPTH.S13271.

9. Allam, G. (2009). Immunomodulatory effects of curcumin treatment on murine schistosomiasis mansoni. Immunobiology. 214,712-727. doi.org/10.1016/j.imbio.2008.11.017.

10. Aggarwal, B.B. \& Sung, B. (2009). Pharmacological basis for the role of curcumin in chronic diseases: an age-old spice with modern targets. Trends in Pharmacological Sciences.30,85-94. doi.org/10.1016/j.tips.2008.11.002.

11. An, F.F. \& Zhang, X.H. (2017). Strategies for preparing albumin-based nanoparticles for multifunctional bioimaging and drug delivery. Theranostics.7,36673689.doi.org/ 10.7150/thno.19365.

12. Alcaraz, L.E., Blanco, S.E., Puig, O.N., Tomas, F. \& Ferretti, F.H. (2000). Antibacterial activity of flavonoids against methicillin-resistant Staphylococcus aureus strains. Journal of Theoretical Biology,205(2),231240.doi.org/10.1006/jtbi.2000.2062.

13. Alsamydai, A. \& Jaber, N. (2018). Pharmacological aspects of curcumin: Review article. International Journal of Pharmacognosy. 5, 313-326.

14. Al-Asmari, F., Mereddy, R., \& Sultanbawa, Y. (2017). A novel photosensitization treatment for the inactivation of fungal spores and cells mediated by curcumin. Journal of Photochemistry and Photobiology. B 173, 301-306. doi: 10.1016/j.jphotobiol.2017.06.009

15. Beevers, C.S. \& Huang, S. (2011). Pharmacological and clinical properties of curcumin. Biologics: Targets and Therapy.1,5-18.doi.org/10.214/BTAT.S17244.

16. Bhat, S., Amin, T. \& Nazir, S. (2015). Biological activities of turmeric (Curcuma longa Linn.) - An Overview. BMR Microbiology 1:1-5.

17. Bolhassani, A.,Javanzad, S., Tayebeh, S.S., Mehrdad, H.M., Hashemi, Mohammad, R.A. \& Sadat, S.M. (2014). Polymeric nanoparticles, potent vectors for vaccine delivery targeting cancer and infectious diseases. Human Vaccines \& Immunotherapeutics, 10,321-332.doi.or $\mathrm{g} / 10.4161 / \mathrm{hv} .26796$.

18. Bhardwaj, M., Singh, B.R., Sinha, D.K., Kumar, V., Prasanna,Vadhana, O.R., Singh, V. S., Nirupama, K.R., Pruthvishree \& Archana, Saraf, B.S. (2016). Potential of Herbal Drug \& Antibiotic Combi a., Basniwal, R.K., Buttar, H.S., Jain, V.K.and Jain, N. (2011). Curcumin nanoparticles: preparation, characterization, and antimicrobial study. Journal of Agricultural and Food Chemistry, 59,2056 -2061.doi.org/10.1021/jf104402t.

19. Bisht, S., Feldmann, G., Soni, S., Ravi, R., Karikar, C., Maitra, A. \& Maitra, A. (2007). Polymeric nanoparticleencapsulated curcumin (nanocurcumin): a novel strategy for human cancer therapy. Journal of Nanotechnology. 5,1 -8. doi.org/ 10.1186/1477-3155-5-3.

20. Bilensoy, E., Sarisozen, C., Esendagl, G., Dogan, L.A., Aktas, Y., Sen, M. \& Mangan, A.N. (2009). Intravesical cationic nanoparticles of chitosan and polycaprolactone for the delivery of Mitomycin $C$ to bladder tumors. International Journal of Pharmaceutics.371170-176.doi.org/ 1 0.1016/j.ijpharm.2008.12.015.

21. Bansal, S.S., Goyal, M., Aquil, F, Vadhanam, M.V. \& Gupta, R.C. (2011). Advanced drug delivery systems of curcumin for cancer chemoprevention. Cancer Prevention Research, 4,1158-1171.doi.org/10.1158/1940-6207.

22. Baban, D. \& Seymour, L.W. (1998). Control of tumour 
vascular permeability.Advanced drug delivery reviews,34,109-119.doi.org/ 10.1016/s0169-409x(98)000039.

23. Calaf, G.M., Ponce-Cusi, R. \& Carrion, F. (2018) Curcumin and paclitaxel induce cell death in breast cancer cell lines. Oncology Report. 40(4),2381-2388

24. Connell, B. J., Chang, S. Y., Prakash, E., Yousfi, R., Mohan, V., Posch, W., Wilflingseder, D., Moog, C., Kodama, E. N., Clayette, P. \&Lortat-Jacob, H. (2016). A CinnamonDerived Procyanidin Compound Displays Anti-HIV-1 Activity by Blocking Heparan Sulfate- and Co-Receptor- Binding Sites on gp120 and Reverses T Cell Exhaustion via Impeding Tim-3 and PD-1 Upregulation. PloS one, 11(10), e0165386. https://doi.org/10.1371/journal.pone.0165386

25. Churchill, M., Chadburn, A., Bilinski, R.T. \& Bertagnolli, M.M. (2000). Inhibition of intestinal tumors by curcumin is associated with changes in the intestinal immune cell profile-Journal of Surgical Research, 89,169-175. doi.o $\mathrm{rg} / 10.1006 / \mathrm{jsre} .2000 .5826$.

26. Cornaglia, G. (2009). "Fighting infections due to multidrugresistant Gram-positive pathogens." Clinical Microbiology and Infection., 15, 209-211. doi.org/10.1111/j.1469-06 91.2009.02737.x.

27. Chauhan, M., Saha, S.\& Roy, A. (2014). Curcumin: A review. Journal of Applied Pharmaceutical Research,2,1828.

28. Cartiera, M.S., Ferreira, E.C., Caputo, C., Egan, M.E., Caplan, M.J.\& Saltzman W.M. (2010). Partial correction of cystic fibrosis defects with PLGA nanoparticles encapsulating curcumin. Molecular Pharmaceutics. 1;7(1),86-93. doi.org/10.1021/mp900138a.

29. Dhama, K., Tiwari, R., Chakraborty, S., Saminathan, M., Kumar, A., K. Karthik., Wani,M.Y., Amarpal , Singh, S. V. \& Rahal,A.(2014). Evidence based antibacterial potentials of medicinal plants and herbs countering bacterial pathogens especially in the era of emerging drug resistance: An integrated update. International Journal of Pharmacology, 10,1-43. doi.org/10.3923/ijp.2014.1.43.

30. Decoster, A., Lemahieu, J.C., Dehecq, E. \& Duhamel, M. (2008). Coursde Bactériologieenligne.Resistance aux antibiotique, Faculté Libre de Médecine, UniversitéCatholique de Lille, http://anne.decoster.free.fr/binde x.html.

31. Duvoix, A., Blasius, R., Delhalle, S., Schnekenburger, M., Morceau, F., Henry, E., Dicato, M. \& Diederich, M. (2005). Chemopreventive and therapeutic effects of curcumin. Cancer Letters, 8,181-190. doi.org/10.1016/j.canlet.2 004.09.041.

32. Deryabin, D., Galadzhieva, A., Kosyan, D. \& Duskaev G. (2019). Plant-Derived Inhibitors of AHL-Mediated Quorum Sensing in Bacteria: Modes of Action. International Journal of Molecular Sciences, 20(22), 5588.

33. Dauda, K., Busari, Z., Morenikeji, O., Afolayan, F., Oyeyemi, O., Meena, J., Sahu, D. \& Panda A. (2017). Poly-D, L-lactic-co-glycolic acid-based artesunate nanoparticles; formulation, antimalarial and toxicity assessments. Journal of Zhejiang University Science B., 18:977-985.doi.org/10.1631/jzus.b1600389.

34. Duggal, D. (2011). Role of nanotechnology in new drug delivery systems. International Journal of Drug Development and Research. 3:4-8.
35. Dhivya, S. \& Rajalakshmi, A.N. (2018). A Review on the preparation methods of curcumin nanoparticles. Pharma Tutor. 6, 6-10.doi.org/10.29161/PT.v6.i9.2018.6.

36. Eades, C., Hughes, S., Heard, K.and Moore, S.P. (2017). Antimicrobial therapies for Gram-positive infections. Clinical Pharmacist., 9(9), online | doi.org/10.1211/CP.20 17.20203363.

37. Elbialy, N. S., Abdelfatah, E. A. \& Khalil, W. A. (2019). Antitumor activity of curcumin-green synthesized gold nanoparticles: In vitro study. Bio. Nano. Science, 9, 813-820.

38. Epstein, J., Sanderson, I.R. \& Macdonald, T.T. (2010). Curcumin as a therapeutic agent: The evidence from in vitro, animal and human studies. British Journal of Nutrition,103:1545-1557.doi.org/ 10.1017/S0007114509 993667.

39. Evans, C.E., Banso, A. \& Samuel, O.A.,(2002). Efficacy of some nupe medicinal plants against Salmonella typhi: an in vitro study. Journal of Ethnopharmacology, 80,2124.doi.org/10.1016/s0378-8741(01)00378-6.

40. Fischbach, M.A. (2011). Combination therapies for combating antimicrobial resistance. Current Opinion in Microbiology, 14,519-523.doi.org/10.1016/j.mib.2011.08.003.

41. Fan, T.X., Chow, S.K.\& Zhang, D. (2009). Biomorphic mineralization: from biology to materials. Progress in Materials Science, 54,542-659.

42. Ferrari, R.,Sponchioni, M., Morbidelli, M. \&Moscatelli, D. (2018). Polymer nanoparticles for the intravenous delivery of anticancer drugs: the checkpoints on the road from the synthesis to clinical translation. Nanoscale 10, 2270122719. doi: 10.1039/C8NR05933K.

43. Feng, S.S. (2004). Nanoparticles of biodegradable polymers for new-concept chemotherapy. Expert Review of Medical Devices. 1,115-125.doi.org/ 10.1586/174344 40.1.1.115.

44. Fang, J., Yu, L., Gao, P., Cai, Y. \& Wei, Y. (2010). Detection of protein-DNA interaction and regulation using gold nanoparticles.Analytical Biochemistry. 399,262-267.doi.or g/ 10.1016/j.ab.2009.11.013.

45. Fritzen-Garcia, M.B., Zanetti-Ramos, B.G., de, Oliveira, C.S., Soldi, V., Pasa, A.A. \& Creczynski-Pasa, T.B. (2009). Atomic force microscopy imaging of polyurethane nanoparticles onto different solid substrates. Materials Science and Engineering, 29, 405-409.doi.org/10.1016/ j.msec.2008.08.012.

46. Gomes,Dde, C.F., Alegrio, L.V., de, Lima, M.E., Leon, L.L. \& Araújo, C.A. (2002). Synthetic derivatives of curcumin \& their activity against Leishmania amazonensis. Arzneimittelforschung, 52,120-124.

47. Grace, D. (2015). Review of evidence on antimicrobial resistance and animal agriculture in developing countries, London, UK: Department for International Development, https://doi.org/10.12774/eodcr.june2015.graced.

48. Gottschalk, F., Sonderer, T., Scholz, R.W. \& Nowack, B. (2009). "Modeled environmental concentrations of engineered nanomaterials $\left(\mathrm{TiO}_{2}, \mathrm{ZnO}, \mathrm{Ag}, \mathrm{CNT}\right.$, fullerenes) for different regions." Environmental Science \& Technology, 43,9216-9222.doi.org/10.1021/es9015553.

49. Gopal, J., Muthu, M. \& Chun, S. (2016). Bactericidal Property of Macro, Micro- and Nanocurcumin: An Assessment. Arabian Journal for Science and Engineering Abbreviation. 41,2087-2093.doi.org/10.1007/s13369-015-1834-3.

50. Guillamet, C.V. \& Kollef, M.H. (2014). Treatment of Gram 
- positive infections in critically ill patients, BMC. Infectious Diseases. 14,92.http://www.biomedcentral.co $\mathrm{m} / 1471-2334 / 14 / 92$.

51. Gwinn, M.R. \& Vallyathan, V. (2006). Nanoparticles: health effects--pros and cons. Environmental Health Perspectives, 114(12),1818-1825.doi.org/10.1289/ehp.8871.

52. Hu, G., Caza, M., Bakkeren, E., Kretschmer, M., Bairwa, G., Reiner, E. \& Kronstad, J. (2017). A P4-ATPase subunit of the Cdc50 family plays a role in iron acquisition and virulence in Cryptococcus neoformans. Cell Microbiology, 19,e12718. doi: $10.1111 / \mathrm{cmi} .12718$

53. Huang, F., Gao, Y., Zhang, Y., Cheng, T., Ou, H., Yang L., Liu, J., Shi, L. \& Liu, J. (2017). Silver decorated polymeric micelles combined with curcumin for enhanced antibacterial activity. ACS Applied Materials \& Interfaces. 9, 16880-16889. doi: 10.1021/ acsami.7b03347

54. Himani, D. \& Joshi, S. (2019). Antimicrobial activity of amides using different synthetic procedure with different microbial strains. International Journal of Universal Pharmacy and Bio Sciences, 8,2319-8141.

55. Igbal, M., Sharma, S.D., Okazaki, Y., Fujisawa, M. \& Okada, S. (2003). Dietary supplementation of curcumin enhances antioxidant and phase II metabolizing enzymes in ddY male mice: possible role in protection against chemical carcinogenesis and toxicity. Pharmacology and Toxicology, 92,33-38. doi.org/10.1034/j.16000773.2003.920106.x

56. Jain, S., Hirst, D.G. \& O'Sullivan, J.M. (2012). Gold nanoparticles as novel agents for cancer therapy. British Journal of Radiology. 85,101-113. doi.org/10.1259/ $\mathrm{bjr} / 59448833$.

57. Jain, K.K.(2008). The handbook of nanomedicine, Humana/Springer, Totowa, NJ,USA, (2008).

58. Jannathul, F.M. \& Lalitha, P. (2015). Apoptotic efficacy of biogenic silver nanoparticles on human breast cancer MCF-7 cell lines. Progress in Biomaterials. 4,113121.doi.org/10.1007/s40204-015-0042-2.

59. Koide, T., Nose, M., Ogihara, Y., Yabu, Y. \& Ohta, N. (2002). Leishmanicidal effect of curcumin in vitro. Biological and Pharmaceutical Bulletin. 25,131133.doi.org/10.1248/bpb.25.131.

60. Karaman, M., Fırıncı, F., Arıkan,Ayyıldız, Z. \&Bahar, I.H. (2013). Effects of imipenem, tobramycin and curcumin on biofilm formation of Pseudomonas aeruginosa strains. MikrobiyolojiBulteni., 47,192-194.doi.org/10.5578/mb.390 2.

61. Kang H.J, Lee S.H, Price J.E. \& Kim L.S. (2009) Curcumin suppresses the paclitaxel-induced nuclear factor-kappa B in breast cancer cells and potentiates the growth inhibitory effect of paclitaxel in a breast cancer nude mice model. Breast Journal, 15(3),223-229.

62. Karuppusamy, C. \&Venkatesan, P. (2017). Role of nanoparticles in drug delivery system : A comprehensive review. Journal of Pharmaceutical Sciences and Research, 9,318-325

63. Kurien, B.T., Singh, A., Matsumoto, H. \& Scofield, R.H. (2007). Improving the solubility \& pharmacological efficacy of curcumin by heat treatment. Assay and Drug Development. Technologies, 5,567-576.doi.org/10.1089/adt.20 07.064 .

64. Kapinova, A., Stefanicka, P., Kubatka, P., Zubor, P., Uramova, S., Kello, M., Mojzis, J., Blahutova, D., Qaradakhi, T., Zulli, A., Caprnda, M., Danko, J., Lasabova, Z.,
Busselberg, D \& Kruzliak P. (2017).Are plantbased functional foods better choice against cancer than single phytochemicals? A critical review of current breast cancer research. Biomedicine and Pharmacotherapy, 96,14651477.

65. Koh, Y.C. \& Pan, M.H (2018). Review on discovery and development of novel phytochemicals which can be used in functional foods. Current Research in Nutrition and Food Science Journal, 6(2),241262.

66. Krausz, A. E., Adler, B. L., Cabral, V., Navati, M., Doerner, J., Charafeddine, R. A., Chandra, D., Liang, H., Gunther, L., Clendaniel, A., Harper, S., Friedman, J. M., Nosanchuk, J. D. \& Friedman, A. J. (2015). Curcuminencapsulated nanoparticles as innovative antimicrobial and wound healing agent. Nanomedicine. 11(1),195206.doi.org/10.1016/j.nano.2014.09.004.

67. Karthikeyan, A ., Senthil, N. \& Min, T, (2020). Nanocurcumin: A Promising Candidate for Therapeutic Applications. Frontiers in Pharmacology.11,487.doi: 10.3389/ fphar.2020.00487.

68. Khan, M. N., Haggag, Y. A., Lane, M. E., Mccarron, P. A., \& Tambuwala, M. M. (2018). Polymeric nanoencapsulation of curcumin enhances its anti-cancer activity in breast (MDA-MB231) and lung (A549) cancer cells through reduction in expression of HIF-1a and nuclear p65 (REL A). Current Drug Delivery, 15, 286-295. doi: 10.2174/1567201814666171019104002

69. Khalil, R.R \& Mustafa YF. (2020). Phytochemical, antioxidant and antitumor studies of coumarins extracted from granny smith apple seeds by different methods. Systematic Reviews in Pharmacy, 11(2),57-63

70. Lima, C.F., Pereira-Wilson, C. \& Rattan, S.I.S. (2011). "Curcumin induces heme oxygenase-1 in normal human skin fibroblasts through redox signaling: relevance for antiaging intervention." Molecular Nutrition and Food Research, 55,430-442. doi.org/10.1002/mnfr.201000221.

71. Li, BC., Li, XL., Lin, H.C. \& Zhou Y. (2018). Curcumin as a Promising Antibacterial Agent: Effects on Metabolism and Biofilm Formation in S. mutans. Biomed Research International, 2018,4508709.

72. Lu, J.M., Wang, X., Marin-Muller, C., Wang, H., Lin, P.H., Yao, Q. \& Chen, C. (2009). Current advances in research and clinical applications of PLGA-based nanotechnology.Expert Review of Molecular Diagnostics, 9,325-341. doi.org/10.1586/erm.09.15.

73. Luz, P.P., Magalhaes, L.G., Pereira, A.C., Cunha, W.R., Rodrigues, V., Andrade, E. \& Silva, M.L. (2012). Curcumin -loaded into PLGA nanoparticles preparation in vitro schistosomicidal activity. Parasitology Research,110,593598.doi.org/ 10.1007/s00436-011-2527-9.

74. Lukita-Atmadja, W., Ito, Y., Baker, G.L. \& McCuskey, R.S. (2002). Effect of curcuminoids as anti-inflammatory agents on the hepatic microvascular response to endotoxin. Shock. 17,399-403.doi.org/10.1097/00024382-20020 5000-00010.

75. Li, M.,Ngadi, M.O. \& Ma, Y. (2014). Optimisation of pulsed ultrasonic and microwave-assisted extraction for curcuminoids by response surface methodology and kinetic study. Food Chemistry. 165,29-34.

76. Lane, D. (2006). Designer combination therapy for cancer. Nature Biotechnology, 24,163-164.doi.org/10.1038/nbt0 
206-163.

77. Mohammed, E.T. \& Mustafa, Y.F. (2020). Coumarins from red delicious apple seeds: Extraction, phytochemical analysis, and evaluation as antimicrobial agents. Systematic Reviews in Pharmacy.11(2),64-70.

78. Martins, C.V., da, Silva, D.L., Neres, A.T., Magalhaes, T.F., Watanabe, G.A., Modolo, L.V., Sabino, A.A., de, Fátima, A. \& de, Resende, M.A.(2009). Curcumin as a promising antifungal of clinical interest. Journal of Antimicrobial Chemotherapy, 63,337-339. doi.org/10.1093/jac/dkn488.

79. Mihaescu, G., Chifiriuc, M.C. \& Dutu, L.M. (2007). Antibiotice is substantechimioterapeutice antimicrobiene. Bucuresti :EdituraAcademieiRomane.

80. Mun, S. H., Kim, S. B., Kong, R., Choi, J. G., Kim, Y. C., Shin, D. W., Kang, O. H., \& Kwon, D. Y. (2014). Curcumin reverse methicillin resistance in Staphylococcus aureus." Molecules, 19,18283-18295.doi.org/10.3390/molecu les191118283.

81. Matsui, T., Yamane, J., Mogi, N., Yamaguchi, H., Takemoto, H., Yao, M. \& Tanaka, I. (2012). "Structural reorganization of the bacterial cell-division protein FtsZ from Staphylococcus aureus." Acta Crystallographica Section D: Biological Crystallography, 68,11751188.doi.org/ 10.1107/S0907444912022640.

82. Mun, S.H., Joung, D.K., Kim, Y.S., Kang, O.H., Kim, S.B., Seo, Y.S., Kim, Y.C., Lee, D.S., Shin, D.W., Kweon, K.T., \& Kwon, D.Y. (2013). Synergistic antibacterial effect of curcumin against methicillin-resistant Staphylococcus aureus. Phytomedicine, j.phymed.2013.02.006.

83. 83. Magalhaes, L.G., Machado, C.B., Morais, E.R., Magalhaes, L.G., Machado, C.B., Morais, E.R., Moreira, E.B., Soares, C.S., da, Silva, S.H., Da, Silva, Filho, A.A. \& Rodrigues, V.(2009). In vitro schistosomicidal activity of curcumin against Schistosoma mansoni adult worms. Journal of Parasitology Research, 104,1197-1201. doi.org/10.1007/s00436-008-1311-y.

84. Moballegh, Nasery, M., Abadi, B., Poormoghadam, D., Zarrabi, A., Keyhanvar, P., Khanbabaei, H., Ashrafizadeh, M., Mohammadinejad, R., Tavakol, S. \&Sethi, G. (2020). Curcumin Delivery Mediated by Bio-Based Nanoparticles: A Review. Molecules, 25, 689.

85. Maheshwari, R.K., Singh, A.K., Gaddipati, J. \& Srimal, R.C. (2006). Multiple biological activities of curcumin: a short review. Life Science, 78,2081-2087. https:// doi.org/10.1016/j.lfs.2005.12.007.

86. Mosovska, S., Petakova, P., Kalinak, M. \&Mikulajova, A. (2016). Antioxidant properties of curcuminoids isolated from Curcuma longa L. Acta ChimicaSlovenica. 9,130135.doi.org/ 10.1515/acs-2016-0022.

87. Maxson, T. \& Mitchell, D.A. (2016). Targeted treatment for bacterial infections: Prospects for pathogen-specific antibiotics coupled with rapid diagnostics. 72,3609-3624. doi.org/10.1016/j.tet.2015.09.069

88. Moghaddam, K.M., Iranshahi, M., Yazdi, M.C. \&Shahverdi, A.R. (2009). The combination effect of curcumin with different antibiotics against Staphylococcus aureus. International Journal of Green Pharmacy, 3,141143.doi.org/10.4103/0973-8258.54906.

89. Mitchison, D. \& Davies, G. (2012). The chemotherapy of tuberculosis: past, present and future. International Jour- nal of Tuberculosis and Lung Disease, 16,724-32. doi.or $\mathrm{g} / 10.5588 / \mathrm{ijtld} .12 .0083$.

90. Makarov, V.V., Love, A.J., Sinitsyna, O.V., Makarova, S.S., Yaminsky, I.V., Taliansky, M.E., \& Kalinina, N.O. (2014). "Green" nanotechnologies: synthesis of metal nanoparticles using plants. Acta Natura. 6,35-44.

91. Mainardes, R.M., Khalil, N.M. \&Gremião, M.P.D. (2010). Intranasal delivery of zidovudine by PLA and PLA-PEG blend nanoparticles. International Journal of Pharmaceutics,395,266-271.doi.org/10.1016/j.jpharm.2010.05.020.

92. Maiti, K., Mukherjee, K., Gantait, A., Saha, B.P. \& Mukherjee, P.K. (2007). Curcumin- phosphoplipid Complex, preparation, therapeutic evaluaton and pharmacokinetic study in rats. International Journal of Pharmaceutics.330,155-163.doi.org/10.1016/j.jpharm.2006.09.025.

93. Mukerjee, A. \&Vishwantha, J.K. (2009). Formulation, characterization and evaluation of curcumin-loaded PLGA nanospheres for cancer therapy. Anticancer Research. 29,3867-3876.

94. Mathew, A., Fukuda, T., Nagaoka, Y., Hasumura, T., Morimoto, H., Yoshida, Y., Maekawa, T., Venugopal, K. \& Kumar, D.S. (2012). Curcumin loaded-PLGA nanoparticles conjugated with Tet-1 peptide for potential use in Alzheimer's disease. PLoS One. 7(3), e3261 6.doi.org/10.1371/journal.pone.0032616.

95. McCall, R.L. \& Sirianni, R.W. (2013). PLGA nanoparticles formed by Single- or Double-emulsion with Vitamin ETPGS. Journal of Visualized Experiments. 82,e51015. doi.org/10.3791/51015.

96. Muqbil, I., Masood, A., Sarkar, F.H., Mohammad, R.M. \& Azmi, A.S. (2011). Progress in nanotechnology based approaches to enhance the potential of chemopreventive agents.

Cancers.3,428-445.doi.org/ 10.3390/ cancers3010428.

97. Mirakabad, F.S.T., Nejati-Koshki, K., Akbarzadeh, A., Yamchi, M.R., Milani, M., Zarghami, N., Zeighamian, V., Rahimzadeh, A., Alimohammadi, S., Hanifehpour, Y. \& Joo, S.W.(2014). PLGA-based nanoparticles as cancer drug delivery systems. Asian Pacific Journal of Cancer Prevention. 15,517-535. doi.org/ 10.7314/ APJCP.2014.15.2.517.

98. Moreno-Vega, A.I., Gomez-Quintero, T., Nunez- Anita, R.E., Acosta-Torres, L.S. \& Castano, V. (2012). Polymeric and ceramic nanoparticles in biomedical applications. Hindawi Publishing Corporation. Journal of Nanotechnology .936041,1-10.doi.org/ 10.1155/2012/936041.

99. Nguyen, D.N., Green, J.J, Chan, J.M., Langer, R. \& Anderson, D.G. (2009). Polymeric materials for gene delivery and DNA vaccination. Advance Materials.21,847-867.

100.Niamsa, N., \& Sittiwet, C. (2009). Antimicrobial activity of Curcuma longa aqueous extract. Jounal of Pharmacology and Toxicology, 4, 173-177.doi.or g/10.3923/jpt.2 009.173.177.

101.Nambiar, S., Osei, E., Fleck, A., Darko, J., Mutsaers, A. J. \& Wettig, S. (2018). Synthesis of curcuminfunctionalized gold nanoparticles and cytotoxicity studies in human prostate cancer cell line. Applied. Nanoscience. 8, 347-357.

102.Nakamura, K., Yasunaga, Y., Segawa, T., Ko, D., Moul, J.W., Srivastava, S. \& Rhim, J.S. (2002). Curcumin downregulates $A R$ gene expression and activation in prostate cancer cellLines. International Journal of Oncology.4,825- 
830.

103.Nair, K.L., Thulasidasan, A.K., Deepa, G., Anto, R.J. \& Kumar, G.S. (2012). Purely aqueous PLGA nanoparticulate formulations of curcumin exhibit enhanced anticancer activity with dependence on the combination of the carrier. International Journal of Pharmaceutics. 425,4452.doi.org/10.1016/j.ijpharm.2012.01.003.

104.Nguyen, T.A. \& Friedman, A.J. (2013). Curcumin: a novel treatment for skin-related disorders. Journal of Drugs in Dermatology, 12,1131-1137.

105.Niederman, M.S. (2005). Principles of appropriate antibiotic use.International Journal of Antimicrobial Agents. 2005,S170- S175.doi.org/ 10.1016/s0924-8579(05)803243.

106.Nair, N., Biswas, R., G“otz, F. \& Biswas, L. (2014). Impact of Staphylococcus aureus on pathogenesis in polymicrobial infections. Infection and Immunity. 82,2162 -2169. doi.org/10.1128/IAI.00059-14

107.Naksuriya, O., Okonogi, S., Schiffelers, R.M. \& Hennink, W.E. (2014). Curcumin nanoformulations: A review of pharmaceutical properties and preclinical studies and clinical data related to cancer treatment. Biomaterials. 35, 3365-3383.doi.org/ 10.1016/j.biomaterials.20 13.12.090.

108.O'Neill, J. (2015). Antimicrobials in agriculture and the environment: reducing unnecessary use and waste. London, UK: Review on Antimicrobial Resistance. Available at: http://amr-review.org/sites/default/files/Antimicrobials in agriculture and the environment - Reducing unnecessary use and waste.pdf.

109.Praditya, D., Kirchhoff, L., Bruning, J., Rachmawati, H., Steinmann, J. \& Steinmann, E. (2019). Anti-infective properties of the golden spice curcumin. Frontier in Microbiology, 10,912. doi.org/10.3389/fmicb.2019.00912.

110.Park, J., Fong, P.M., Liu, J., Russell, K.S., Booth, K.J., Saltzman, W.M. \& Fahmy, T.M. (2009). PEGylated PLGA nanoparticles for the improved delivery of doxorubicin. Nanomedicine. 5,410-418.doi: 10.1016/ j.nano.2009.02.002

111.Priyadarsini, K.I. (2014). The chemistry of curcumin: from extraction to therapeutic agent. Molecules.19,2009120112.doi.org/10.3390/molecules191220091.

112.Quispe, Soto, E.T. \& Calaf, G.M. (2016) Effect of curcumin \& paclitaxel on breast carcinogenesis. International Journal of Oncology. 49(6),2569-2577.

113.Rai, M., Pandit, R., Gaikwad, S., Yadav, A. \& Gade, A. (2015). Potential applications of curcumin and curcumin nanoparticles: from traditional therapeutics to modern nanomedicine. Nanotechnology Review.4,161-172.

114.Rejhova, A.., Opattova, A., Cumova, A., Sliva, D. \& Vodicka, P. (2018). Natural compounds and\& combination therapy in colorectal cancer treatment. Europian Journal of Medical Chemistry.144,582-594.doi: 10.1016/ j.ejmech.2017.12.039

115.Richman, D.D. (2001). HIV chemotherapy. Nature. 410,995-1001. doi.org/10.1038/35073673.

116.Rai, M., Yadav, A. \&Gade, A. (2009). Silver nanoparticles as a new generation of antimicrobials. Biotechnology advances.27,76-83.

117.Rai, D., Singh, J.K., Roy, N. \& Panda, D. (2008). Curcumin inhibits FtsZ assembly: an attractive mechanism for its antibacterial activity. Biochemical Journal. 410,147155. doi.org/10.1042/BJ20070891.
118.Roacho-Pérez, J.A., Ruiz-Hernandez, F.G., ChapaGonzalez, C., Martínez-Rodríguez, H.G., FloresUrquizo, I.A., Pedroza-Montoya, F.E., Garza-Treviño, E.N., Bautista-Villareal, M., García-Casillas, P.E. \& Sánchez-Domínguez, C.N. (2020). Magnetite Nanoparticles Coated with PEG 3350-Tween 80: In Vitro Characterization Using Primary Cell Cultures. Polymers. 12, 300.

119.Redondo-Blanco S, Fernandez J, Gutierrez-del-Rio, I., Villar, C.J. \& Felipe Lombo. (2017) New insights toward colorectal cancer chemotherapy using natural bioactive compounds. Frontier in Pharmacology. 8,109.

120.Rudrappa, T.\& Bais, H.P. (2008). Curcumin, a known phenolic from Curcuma longa, attenuates the virulence of Pseudomonas aeruginosa PAO1 in whole plant and animal pathogenicity models. Journal of Agricultural and Food Chemistry. 56,1955-1962.doi.org/10.1021/ jf072591j.

121.Rasmussen, H.B., Christensen, S.B., Kvist, L.P. \&Karazmi, A. (2000). A simple and efficient separation of the curcumins, the antiprotozoal constituents of Curcuma longa. Planta Medica, 66,396-398. doi.org/10.1055/s-2000-8533.

122.Rafiee, Z., Nejatian, M., Daeihamed, M., \& Jafari, S. M. (2019). Application of different nanocarriers for encapsulation of curcumin. Critical Reviews in Food Science and Nutrition, 59, 3468-3497. doi: 10.1080/104 08398.2018.1495174.

123.Suresh, S., Sankar, P., Telang, A. G., Kesavan, M. \& Sarkar, S. N. (2018). Nanocurcumin ameliorates Staphylococcus aureus-induced mastitis in mouse by suppressing NF-kB signaling and inflammation. International Immunopharmacology. 65,408-412. doi: 10.1016/j.intimp.2018.10.034

124.Salehi, B., Stojanović-Radić, Z., Matejić, J., SharifiRad, M., Anil Kumar, N. V., Martins, N. \& Sharifi-Rad, J. (2019). The therapeutic potential of curcumin: A review of clinical trials. European Journal of Medicinal Chemistry. 163, 527-545. https://doi.org/10.1016/j.ejm ech.2018.12.016

125.Singh, C. K., Siddiqui, I. A., El-Abd, S., Mukhtar, H. \& Ahmad, N. (2016).Combination chemoprevention with grape antioxidants. Molecular Nutrition \& Food Research. 60(6), 1406-1415.

126.Steinmann, J., Buer, J., Pietschmann, T. \& Steinmann, E. (2013). Anti-infective properties of epigallocatechin-3 -gallate (EGCG), a component of green tea. British Journal of Pharmacology. 168,1059-1073.doi.or g/10.1111/bph.12009.

127.Singh, P. \& Panda, D. (2010). Fts Z inhibition: a promising approach for anti-staphylococcal therapy, Drug News Perspect., 23,295-304.doi.org/10.1358/dnp.20 10.23.5.1429489.

128.Sanpui, P., Chattopadhyay, A. \& Ghosh, S.S. (2011). Induction of apoptosis in cancer cells at low silver nanoparticle concentrations using chitosan nanocarrier.ACS Applied Materials \& Interfaces, 3,218-228. doi.org/10.1021/am100840c.

129.Shailendiran, D., Pawar, N., Chanchal, A., Pandey, R.P., Bohidar, H.B. \& Verma, A.K. Characterization and antimicrobial activity of nanocurcumin and curcumin, in Proceedings of the International Conference on Nano- 
science, Technology and Societallmplications (NSTSI'11), pp. 1-7, IEEE, December 2011.

130.Stevanovic, M., Maksin, T., Petkovic, J., Filipic, M. \& Uskokovic, D. (2009). An innovative, quick and convenient labeling method for the investigation of pharmacological behavior and the metabolism of Poly(DL-lactidecoglycolide) nanospheres. Nanotechnology. 20,112.doi.org/10.1088/0957-4484/20/33/335102.

131.Shishodia, S., Chaturvedi, M.M, \& Aggarwal, B.B. (2007). Role of curcumin in cancer therapy. Current Problems in Cancer.31,243-305.doi.org/10.1016/ j.currproblcancer.2007.04.001.

132.Saengkrit, N., Sanitrum, P., Woramongkolchai, N., Saesoo, S., Pimpha, N., Chaleawlert-Umpon, S., Tencomnao, T. \& Puttipipatkhachorn, S. (2012). The PEl-introduced CS shell/PMMA core nanoparticle for silencing the expression of E6/E7 oncogenes in human cervical cells. Carbohydrate Polymers.15;90(3),1323-9.doi.org/ 10.1016/ j.carbpol.2012.06.079.

133.Stevanovic, M. \&Skokovic, D. (2009). Poly(lactide-coglycolide)-basedmicro and nanoparticles for the controlled drug delivery of vitamins. Current Nanoscience. 5,1-14.

134.Stevanovic, M., Radulovic, A., Jordovic, B. \& Uskokovic, D.P. (2008). Poly(DL-lactide-co-glycolide) Nanospheres for the sustained release of folic acid. Journal of Biomedical Nanotechnology, 4,349-358.doi.or g/10.1166/ jbn.2008.321.

135.Surh, Y.J., Chun, K.S., Cha, H.H., Han, S.S, Keum, Y.S., Park, K.K. \& Lee, S.S.(2001). Molecular mechanisms underlying chemopreventive activities of anti-inflammatory phytochemicals: down-regulation of COX-2 and iNOS through suppression of NF-kappa B activation. Mutation Research, 480-481, 243-268.doi.org/ 10.1016/s0027-5107 (01)00183-x.

136.Smerak, P., Polivkova, Z., Sestakova, H., Stetina, R., Barta, I., Langova, M., Turek, B. \& Bartova, J. (2006). Antimutagenic effect of curcumin and its effect on the immune response in mice. Czech Journal of Food Science. 24,72-83.

137.Sharma, R.A., Steward, W.P. \&Gescher, A.J. (2007) Pharmacokinetics and pharmacodynamics of curcumin. The molecular targets and therapeutic uses of curcumin in health and disease. New York: Springer, pp.453-470.

138.Sharma, V.K., Ria, R.A. \& Lin, Y. (2009). Silver nanoparticles: Green synthesis and their antimicrobial activities.Advances in Colloid and Interface Science. 145,8396.doi.org/ 10.1016/j.cis.2008.09.002.

139.Thadakapally, R., Aafreen, A., Aukunuru, J., Habibuddin, M., \& Jogala, S. (2016). Preparation and characterization of PEG-albumin-curcumin nanoparticles intended to treat breast cancer. Indian Journal of Pharmaceutical Science. 78, 65. doi: 10.4103/0250-474X.180250.

140.Turos, E., Shim, J.Y., Wang, Y., Greenhalgh, K., Reddy, G.S., Dickey. S. \& Lim, D.V. (2007). Antibiotic-conjugated polyacrylate nanoparticles: New opportunities for development of anti-MRSA agents. Bioorganic \& Medicinal Chemistry Letters. 17,53-56. doi.org/ 10.1016/ j.bmcl.2006.09.098.

141.Tongnuanchan, P.\& Benjakul, S. (2014). Essential oils: extraction, bioactivities, and their uses for food preservation. Journal of Food Science. 79,1231 1249.doi.org/10.1111/1750-3841.12492.
142.Teow, S.Y., Liew, K., Ali, S.A., Khoo, A.S.B. \& Peh, S.C. (2016). Antibacterial action of curcumin against Staphylococcus aureus: A Brief Review. Journal of Tropical Medicine.10,2853045.doi:org/10.1155/2016/2853045.

143.Taccola, L.,Raffa, V.,Riggio, C., Vittorio, O.,Lorio, M.C., Vanacore, R., Pietrabissa, A. \& Cuschieri, A. (2011). Zinc oxide nanoparticles as selective killers of proliferating cells. International Journal of Nanomedicine. 6,1129-1140. doi.org/10.2147/IJN.S16581.

144.Tomar, A. \& Garg, G. (2013). Short Review on application of gold nanoparticles. Global Journal of. Pharmacology. 7,34-38.doi.org/ 10.5829/idosi.gjp.2013.7.1.66173.

145.Thanh, N.T.K.\& Green, L.A.W. (2010). Functionalisation of nanoparticles for biomedical applications. Nano Today. 5,213-230. doi.org/ 10.1016/j.nantod.2010.05.003.

146.Tyagi, P., Singh, M., Kumari, H., Kumari, A. \& K. Mukhopadhyay. (2015). Bactericidal activity of curcumin I is associated with damaging of bacterial membrane, PLOS ONE. 10, 3, e0121313.

147.Tan, B., \& Norhaizan, M. E.. (2019). Curcumin combination chemotherapy: the implication and efficacy in cancer. Molecules. 24, 2527. doi: 10.3390/ molecules24142527.

148.Umrani, R.D. \& Paknikar, K.M.(2014). Zinc oxide nanoparticles show antidiabetic activity in streptozotocininduced Type 1 and 2 diabetic rats. Nanomedicine. 9,89104.doi.org/10.2217/nnm.12.205.

149.Upendra, R.S., Khandelwal, P. \& Reddy, A.H.M. (2011). "Turmeric powder (Curcuma longa Linn.) as an antifungal agent in plant tissue culture studies." International Journal of Engineering Science. 3,7899-7904.

150.Ungphaiboon, S., Supavita, T., Singchangchai, P., Sungkarak, S., Rattanasuwan, P. \& Itharat, A. (2005). Study on antioxidant and antimicrobial activities of turmeric clear liquid soap for wound treatment of HIV patients, Songklanakarin. Journal of Science \& Technology.27,569 -578 .

151.Verma, R. J., Chakraborty, B. S., Patel, C. \& Mathuria, N. (2008). Curcumin ameliorates aflatoxin-induced changes in SDH and ATPase activities in liver and kidney of mice. Acta Poloniae Pharmaceutica. 65, 415-419.

152.Wang, P., Wang, X., Wang, L., Hou, X., Liu, W. \& Chen, C. (2015). Interaction of gold nanoparticles with proteins and cells. Science and Technology of Advanced Materials. 16,034610.doi.org/ 10.1088/1468-6996/16/3/034610.

153.Woodford, N. \& Livermore, D.M.(2009). Infections caused by Gram-positive bacteria: a review of the global challenge. Infection.59,S4-S16. doi.org/10.1016/S0163-4453 (09)60003-7.

154.Wang, J., Zhou, X., Li, W., Deng, X., Deng, Y. \& Niu, X. (2016). Curcumin protects mice from Staphylococcus aureus pneumonia by interfering with the self-assembly process of $\alpha$-hemolysin. Scientific Reports. 6,28254.doi.org/10.1038/srep28254.

155.Walsh, C. (2000). Molecular mechanisms that confer antibacterial drug resistance. Nature. 406,775781.doi.org/10.1038/35021219.

156.Worthington, R.J. \& Melander, C. (2013). Combination approaches to combat multi-drug resistant bacteria. Trends in Biotechnology. 31,177-184.doi.org/10.1016/ j.tibtech.2012.12.006.

157.Wang, Y., Lu. Z., Wu, H. \& Lv, F. (2009). Studyon the antibiotic activity of microcapsule curcumin against food- 
borne pathogens. International Journal of Food Microbiology. 136, 71-74. doi.org/10.1016/j.ijfoodmi cro.2 009.09.001.

158.Wang, Y.F., Shao, J.J, Zhou, C.H., Zhang, D.L., Bie, X.M. \&Lv, F.X. (2012). Food preservation effects of curcumin microcapsules. Food Control. 27,113-117.

159.Xiaoling, L. \& Haskara., R.J. (2006). Design of controlled release drug delivery systems. MacGraw-Hill, New York.

160.Xie, M., Fan, D., Li, Y., He, X., Chen, X., Chen, Y., Zhu, J., Xu, G., Wu, X.amd Lan, P. (2017). Supercritical carbon dioxide-developed silk fibroin nanoplatform for smart colon cancer therapy. International Journal of Nanomedicine. 12,7751-7761.

161.Yallapu, M.M., Maher, D.M., Sundram, V., Bell, M.C., Jaggi, M. \& Chauhan, S.C. (2010). Curcumin induces chemo/radio-sensitization in ovarian cancer cells and curcumin nanoparticles inhibit ovarian cancer cell growth. Journal of Ovarian Research. 3,11-12.

162.Zhan, Y., Chen, Y., Liu, R.,Zhang, H. \& Zhang, Y.(2014). Potentiation of paclitaxel activity by curcumin in human breast cancer cell by modulating apoptosis and inhibiting
EGFR signaling. Archives of Pharmacal Research.37 (8), 1086-1095.

163.Zhang, Y., Li, H., Zhang, J., Zhao, C., Lu, S., Qiao, J. \& Han, M. (2020). The combinatory effects of natural products and chemotherapy drugs and their mechanisms in breast cancer treatment. Phytochemistry Reviews.19,1179-1197.

164.Zaharieva, M. M., Kroumov, A. D., Dimitrova, L., Tsvetkova, I., Trochopoulos, A., Konstantinov, S. M., Berger, M.R., Momchilova M., Yoncheva, K. \& Hristo Najdenski, H. M. (2019). Micellar curcumin improves the antibacterial activity of the alkylphosphocholines erufosine and miltefosine against pathogenic Staphyloccocus aureus strains. Biotechnology and Biotechnological Equipment. 33, 3853. doi: 10.1080/13102818.2018.1533792

165.Zhang, N.-Y., Qi, M., Zhao, L., Zhu, M.-K., Guo, J., Liu, J., Gu, C. Q., Rajput, S. A., Krumm, C. S., Qi, D. S. \& Sun, L. H.(2016). Curcumin prevents aflatoxin B1 hepatoxicity by inhibition of cytochrome P450 isozymes in chick liver. Toxins 8,E327. doi: 10.3390/toxins8110327. 